\title{
1G5: A Calmodulin-binding, Vesicle-associated, Protein Kinase-like Protein Enriched in Forebrain Neurites
}

\author{
Martin Godbout,, ${ }^{1, a}$ Mark G. Erlander, ${ }^{1}$ Karl W. Hasel, ${ }^{1}$ Patria E. Danielson, ${ }^{1}$ Kenneth K. Wong, ${ }^{1}$ Elena L. F. \\ Battenberg, ${ }^{2}$ Pamela E. Foye, ${ }^{1}$ Floyd E. Bloom, ${ }^{2}$ and J. Gregor Sutcliffe' \\ Departments of ${ }^{1}$ Molecular Biology and ${ }^{2}$ Neuropharmacology, The Scripps Research Institute, La Jolla, California 92037
}

\begin{abstract}
We have characterized cDNA clones of 1G5, an mRNA highly enriched in the mammalian forebrain that encodes a 504residue protein found in association with perikaryal membranes and neurites. The protein, which accumulates predominantly postnatally, is associated with vesicles in both axons and dendrites. The sequence of the 1 G5 protein highly resembles those of protein kinases with serine/threonine specificity; however, although most residues universally conserved among protein kinases are present, a few signature residues are absent from the $1 \mathrm{G} 5$ protein. Furthermore, although recombinant $1 \mathrm{G} 5$ protein binds calmodulin in the presence of calcium, it lacks kinase activity with a sample substrate.
\end{abstract}

[Key words: vesicle, calcium, calmodulin, protein kinase, forebrain, plasticity]

It is widely known that thousands of proteins are expressed exclusively or in a highly enriched fashion by the mammalian CNS (Sutcliffe, 1988). Many of these are expressed in patterns of neuronal subsets, reflecting anatomical or neurosystem subdivisions (or both) within the brain hierarchy, and these proteins presumably account for some of the functional specializations of the subsets. Evidence supporting this assertion has been rapidly accumulating: one might consider as examples the G-protein-coupled receptor superfamily, with some members expressed exclusively in the neurons of the olfactory epithelium and contributing to olfactory function (Buck and Axel, 1991), whereas other members, $D_{1}$ dopamine receptors, are located primarily in the striatum and contributing to extrapyramidal motor activity (Zhou et al., 1990). The method of subtractive hybridization (e.g., Travis and Sutcliffe, 1988) provides a means to identify cDNA clones of undiscovered mRNAs that encode anatomically restricted proteins and therefore to learn about their natures.

Because the distribution of many of the thousands of neuronal

Received Jan. 11, 1993; revised Apr. 29, 1993; accepted May 20, 1993.

We thank Ana Dopazo for providing her rat hippocampal cDNA library, Mike Buchmeier for peptide synthesis, Mary Kennedy for providing her $\alpha$ CaMKII cDNA clone, Gabriel Travis and Juan Bernal for their contributions at the early stages of this study, Frank Burton, Ana Dopazo, Jeff Falk, Dan Gerendasy, Luis de Lecea, and Sonja Forss-Petter for critical comments, and Linda Elder for preparing the manuscript. This work was supported in part by grants from the NIH (NS22347, NS22111).

Correspondence should be addressed to J. G. Sutcliffe, Department of Molecular Biology, The Scripps Research Institute, 10666 North Torrey Pines Road, La Jolla, CA 92037.

aPresent address: Le Centre de recherche, Universite Laval, 2705 Boulevard Laurier, Ste.-Foy, Quebec G1V 4G2 Canada.

Copyright $\odot 1994$ Society for Neuroscience $0270-6474 / 94 / 140001-13 \$ 05.00 / 0$ proteins is not anatomically uniform, the ensembles of biochemical processes differ among various subsets of neurons from different brain regions. Furthermore, because of protein compartmentalization within the highly elaborate morphology of neurons, the ensembles of biochemical processes differ within neurons themselves. For example, type II calcium/calmodulindependent protein kinase (CaMKII), a molecule involved in long-term potentiation, is highly enriched in the postsynaptic density (Kennedy et al., 1983; Silva et al., 1992a,b), whereas GAP43, also associated with forms of plasticity, is highly enriched in axonal processes (Skene, 1989).

To learn about molecules of particular importance to the function of mammalian forebrain, we have used subtractive strategies for identifying cDNA clones of mRNAs enriched in cerebral cortex compared to cerebellum (Travis et al., 1987; Travis and Sutcliffe, 1988; Bernal et al., 1990; Watson et al., 1990). We describe here one of these cortex-enriched mRNAs that encodes a putative protein with domains similar to members of the protein kinase superfamily. We have detected the protein and shown by immunoelectron microscopy that it is associated with membranes and vesicles present in neurites of subsets of noncerebellar neurons. We have produced the protein in bacteria and shown that the expressed protein binds to calmodulin but neither phosphorylates a peptide substrate of CaMKII nor contains a complete ATP-binding site.

\section{Materials and Methods}

Nucleic acids methodologies. For library construction and Northern blotting, total RNA was isolated from dissected tissues of developing and adult Sprague-Dawley rats (Charles River) by extraction with guanidinium isothiocyanate (Sambrook et al., 1989). Oligo(dT)-cellulose chromatography (Aviv and Leder, 1972) was used to enrich for polyA ${ }^{+}$ RNA. For anchored polymerase chain reaction (PCR) experiments, RNA was extracted from frozen tissue (Zivic-Miller) and polyA-selected using Fast Track (Invitrogen).

cDNA was synthesized from adult male rat hypothalamic mRNA according to a modified version of the procedure described by Gubler and Hoffman (1983) and cloned into Zap II (Stratagene), using EcoRI as cloning site. Apparently full-length IG5 clones were isolated by screening the hypothalamic library with the $6 \mathrm{E} 9 \mathrm{cDNA}$ insert. Twentytwo positive, full-length clones were obtained from $1 \times 10^{6}$ phage plated.

The 3.0 kilobase $(\mathrm{kb})$ fragment containing the full cDNA insert of the shorter $1 \mathrm{G} 5$ clone (Fig. 1) was digested with exonuclease III to generate overlapping subclones in pBluescript $\mathrm{SK} \pm$ (Stratagene). DNA sequences were determined by the dideoxy chain termination method with $\alpha-{ }^{35} \mathrm{~S}$ dATP $(3000 \mathrm{Ci} / \mathrm{mm})$ as label (Sanger ct al., 1977), using the Scquenase 2.0 kit (United States Biochemical). The sequence of the longer cDNA insert was determined, and that of the shorter clone confirmed, by the partial chemical degradation method (Maxam and Gilbert, 1977).

For Northern blots, $10 \mu \mathrm{m}$ per lane of each mRNA sample was resolved by electrophoresis on a $1.2 \%$ agarose, $1.2 \mathrm{~m}$ formaldehyde gel, transferred to nitrocellulose membrane (Amersham, Hybond C Extra) 
ProSerGluValThrAspArgTyrAspLeuGlyGlnVal ValLysThrGluGluPheCysGIuIlePheArgAlaLysAspLysThrThr

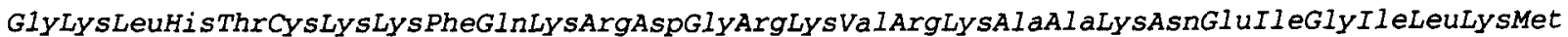
GGCAAGCTGCATACCTGCAAGAAATTCCAGAAGCGTGATGGCCGCAAGGTICGGAAGGCAGCCAAGAACGAGATTGGAATCCTGAAGATG

ValLysHisProAsnIleLeuGlnLeuValAspVal PheVal ThrArgLysGluTyrPheIlePheLeuGluLeuAlaThrGlyArgGlu GTAAAGCACCCCAACA TCCTGCAGCTGGTAGATGTGTTTGTGACCCGCAAAGAATACTTCATCTTTCTGGAGCTGGCCACGGGGAGGGAG

Val PheAspTrpI leLeuAspglnGlyTyrTyrSerGluArgAspThrSerAsnValValArgGlnVal LeuGluAlaValAlaTyrLeu GTGTTTGACTGGATCCTGGACCAGGGCTACTACTCGGAGCGAGACACGAGCAACGTGGTGCGGCAGGTCCTGGAGGCTGTGGCCTACTTG

TyrGlyArgProValAspCysTrpalaIleGlyVal IleMet TyrIleLeuLeuSerGlyAsnProProPheTyrGluGluValGIuGlu

AspAspTyrGIUASnHisAspLysAsnLeUPheArgLysIleLeUAlaGlyAspTyrGluPheAspSerProTyrTrpAspAspIleSer GATGACTATGAGAACCATGATAAGAATCTCTTCCGCAAGATCCTCGCCGGTGACTATGAGTTTGACTCTCCGTACTGGGATGATATTTCT

GInAlaAlaLysAspLeUVaIThrArgLeUMetGIUValGluGInAspGInArgIleThrAlaGluGluAlaIleSerHisGluTrpIle CAAGCAGCCAAAGACCTGGTCACAAGGCTGATGGAGGTGGAGCAAGACCAGCGGATCACCGCCGAAGAGGCCATCTCCCATGAATGGATT

SerGIyAsnAlaAlaSerAspLysAsnIleLysAspGIyValCYsAlaGInIleGIULYsAsnPheAlaArgAlaLysTrpLYSLYSAIa TCTGGCAATGCAGCTTCTGATAAGAACATCAAGGATGGCGTCTGTGCCCAGATCGAGAAGAACTTTGCCAGAGCCAAGTGGAAGAAGGCC

ProAlaThrAspGlySerIleThrProAlaThrAspGlySerValThrProAlaThrAspArgSerAlaThrProAlaThrAspGlyArg CCAGCCACTGACGGGAGCATCACCCCAGCCACTGATGGGAGTGTCACTCCAGCTACTGACAGGAGTGCTACACCAGCTACTGATGGGAGA

CTCACTGTATATAGAGTCACTGGCATGATGCCCTAGCTCCCCCCAAGCTCCCTCATCCCAGTGGGGCATGCCTGGGGGCCATGGGAGAGC AGTGTCGTCTCCTGTGTGGATGTATGTGAGTGGTGGGCAGGCCAGAGGCAGGGCCAGCCCCAGCCCCTGCATGGATTCCTTGTGGCTTTC TGTCTTTCGCTAGCTTCACCAGTTTCTGTTCCTTGTGGGATGCTGCTCTAGGGATACTCAGGGGGTCCTTGCTCTCCTTCCCTTCCCGTC TTCTCATGTCCCCAGGCAGGCCCTGCAAGCCTCATACTTTCCCAGGCCCTAAATGGGTGGCCTTGCCCTGAGAGCTGGTCCTCCAGCGAG GCCCTGTCAGCAGTGTTAGGCTCCTGCACACGAAGGTGTGTGTACCTGTGGTGTTTGGGCTGCTCTAGGAGTAGATGCTGGCTGTAAAAG ATGATGCAGAAATCTAGGGCAGTGTGCTTTAAGTTAAGTCTGGTCACATGGTTGGGGGCAGGCACTGCATGTTAGCTGTGGGGA TCCTCA GAAGTGGGAGAGAGAATGGGTAGAAGCGTCCATCTTTTTCCCTGGGTGGGGGTGGGGATCTTCCCTCTGAAGATCCTTGTGTTATTTCAT AGCCTCCTGAGTCCTGTAGTGGGTTGCTCTGCATCCTGATTCTTACGACACTCCAAAGGAAGAGAGAAACATGTTGGATGCAGCAGCGAT GCCTAGGAGAACAGAGTACAGGGCCAGCAGCACCAGTGCCCCAGCCTATCTGGGTCTTCTCTGTGAGCGAGATAGGGAGGGCTGGTGTCC CCCATGGTCTTCCTAGATGCCACTACCAACGAAGAGACCTTTCCCATAACCACCTCATGCAGGCTCAGGCCATAAATCCTCTTCCTCCCA GGGAGGCATGGCAGTACCTCATAGGCTGCTTTGGGAGCTTGCTTTTCACAGCAGCAGATTTTCTGTTCTTCGTTCAGCAATGCGGAGAGG CTTTACCTCTGTGTCTACTACCAGAGGCTGAGGTATCGCTCAGCCATGGGATGAGGAAGTAGAATAAGATTTCCCAGCTCCCTGAGGGAT GCTCTCGGCAGGCACCCTTGGTCAGACTCTACCACAGCCTGCACAGGCAGCCACGCTGGTCCTTGCCCTTGCTCGGCACTCCATGGTGGT ACTGCCCTTCTCCCTGCATGCCTGTGGGTCTGCTCTGGTATGTGAAGGTTGGTGGGCTAACTGTGTGCCTGCTGAACCTGGCAAATAAAC GTCACCCTGCAAAGCCTCTGGCCACCCTCTTGCCTTTGCTTCCTCTGTCCTATTGGGGAGGAGCCTATGGAAGGCAGTGTGGGAGGGAAG AGGCCATGGGAGCAGTTCCGGGTAGCGGCTGATGCTCAGTGCATTGCTTGGGGTAAGAGTGGAGGTCACCTTCTCCGATGTGTACCTGGA TGATGTTAATGGTAAATCCTCTGGGCTCAAAAAAACCATGAGTGGTGTGTTTAAGCCAAGAAGTATCCCTAGCCGAGCACTGAAGGGCTG ATGCTTTTCCAATTCTTGTTGACGAAGAGCCTTTGTCTTAACTTGGACATAGAGGTGGAATCCACTCAGGGACAACCACTATAGGAAGTG ACCTTGTTCATGGGCACAGTGGGCCTCCTTGGGCTGGGAGAAAGTGGGGTTCACAAGT"T"TGTGCTGTATGTTGATGCCTACTTCCTG TGAATACCTGTGCTTTCCACTTAGACCAAAAAGATTTCATTCTGTCTTCCCTGGCTGACGCAGACCTGCTTTATAATATGGAGTCATGTA TGTTCCTTTTGGGGGAGTAATATTGCTAATGATACTATAAAAATCCCTAAGGAGATTCGCTTCAACTCGGAGGGGCTTTGGTAAACTCAT CTGGGT"TGCT"IT"TCAGGGAGGACCTTAAAT"TATCTGATGTGGGAATAATAAAGA 
(Thomas, 1980), and hybridized to a ${ }^{32} \mathrm{P}$-labeled insert from 1G5. Blots were hybridized in $56 \%$ formamide at $37^{\circ} \mathrm{C}$ as described previously (Sutcliffe et al., 1982) and washed at high stringency in $0.1 \times \operatorname{SSC}(1 \times$ SSC is $0.15 \mathrm{~m} \mathrm{NaCl}, 0.015 \mathrm{~m}$ sodium citrate), $0.5 \%$ SDS at $68^{\circ} \mathrm{C}$. To confirm that similar amounts of intact RNA were loaded in each gel lane, blots were stripped and hybridized or simultaneously hybridized with a ${ }^{32} \mathrm{P}$-cDNA probe for ubiquitously expressed cyclophilin mRNA (Danielson et al., 1988).

Antisera and Western blotting. To obtain 1G5-specific antisera, 400 $\mu \mathrm{g}$ of synthetic peptides (1G5-4: GATGQAPPSSKGE, residues 477489; 1G5-5: KAAATPEPAVAQPD, residues 458-471), corresponding to regions within the $1 \mathrm{G} 5$ sequence, was conjugated with glutaraldehyde to an equal weight of the carrier protein edestin. The conjugates were used to immunize rabbits as previously described (Green et al., 1982; Sutcliffe et al., 1983).

Protein extracts were prepared from various rat tissues by homogenization in $0.16 \mathrm{M} \mathrm{NaCl}, 11 \mathrm{~mm}$ sodium phosphate, $\mathrm{pH} 7.4$, and solubilization in SDS-extraction buffer $(125 \mathrm{~mm}$ Tris $\mathrm{HCl}$, pH $6.8,4.6 \%$ SDS, $10 \% \beta$-mercaptoethanol). Extracts were boiled and centrifuged at $10,000 \times g$ at room temperature to remove cellular debris. Aliquots $(50 \mu \mathrm{g})$ of the supernatants were resolved by electrophoresis on $10 \%$ SDS-polyacrylamide gels and transferred to nitrocellulose filters by electroblotting (Towbin et al., 1979). Filters were preincubated overnight at $4^{\circ} \mathrm{C}$ with Blotto solution ( $5 \%$ nonfat milk, 12 mm sodium phosphate $56 \mathrm{mM} \mathrm{NaCl}, \mathrm{pH} 7.4$ ), incubated in a sealed plastic bag with diluted $1 \mathrm{G} 5$ anti-peptide antisera overnight at room temperature, washed three times for $10 \mathrm{~min}$ with Blotto solution, and rinsed briefly with water. Immunoreactive polypeptide bands were visualized enzymatically in a secondary antibody reaction using horseradish peroxidase conjugated to goat anti-rabbit IgG. Peroxidase activity was detected by incubation for $1 \mathrm{~min}$ with the Amersham enhanced chemiluminescence detection system and exposure to $\mathrm{x}$-ray film. For blocking experiments, $60 \mu \mathrm{g}$ of $1 \mathrm{G} 5$ synthetic peptide was combined overnight at $4^{\circ} \mathrm{C}$ with diluted antipeptide antisera prior to incubation with Western filters. Blocking completely eliminated immunoreactivity.

Anchored PCR. PolyA-selected RNA extracted from rat hippocampus was converted to first-strand cDNA using random hexamer oligonucleotide primers and MMLV-reverse transcriptase, and the cDNAs were subsequently tailed with dGTP using terminal transferase. Anchored PCR (Frohman et al., 1988) was performed using this dG-tailed cDNA as template in a reaction with a primer complementary to nucleotides 478-501 of 1 G5 (5'-ACGTCCGCGGAAGCTTGCTCGTGTCTCGCTCCGAGTAGTA-3') and an anchored primer (5'-GCACCGCGGAGCTCAAGCTTCCCCCCCCCCCCCCCCC-3'). The PCR products were separated by gel electrophoresis, the DNA transferred onto nitrocellulose, and the filter was hybridized with a radioactively labeled oligonucleotide (5'-GTTTGACTGGATCCTGGACCAGGGC-3') representing nucleotides $453-477$ of the 1 G5 sequence. A major band of approximately 500 base pairs (bp) was detected, as well as a smear of shorter material. DNA larger than $100 \mathrm{bp}$ was eluted, concentrated, subcloned into the HindIII site of pKS Bluescript (Stratagene), and transformed into DH12S (GIBCO/Bethesda Research Labs) cells by electroporation, as suggested by the supplier. Individual clones were grown overnight. DNA was extracted by the lysozyme/boiling method (Maniatis et al., 1982), denatured in $0.2 \mathrm{~N} \mathrm{NaOH}$, and purified on Sephacryl $\$ 400$ spin columns, and sequences were determined on doublestranded templates.

Computer searches. The nucleic acid (Genbank 72.0) and protein (Swiss-prot 22.0) databases were searched (6/92) with the entire coding region of $1 \mathrm{G} 5$ and various subregions using the FASTDB program (Brutlag et al., 1990; Intelligenetics, Inc.). In addition, a database developed by Hanks and Quinn (1991), containing the amino acid sequences from the catalytic region of 206 protein kinases, was searched with the putative catalytic region of $1 \mathrm{G} 5$. Because $1 \mathrm{G} 5$ lacks the conserved sequences in subdomain I of the catalytic region, we used the initial methionine residue of $1 \mathrm{G} 5$ for the $\mathrm{N}$-terminal boundary of the $1 \mathrm{G} 5$ catalytic region.

In situ hybridization. In situ hybridization was performed on $20-\mu \mathrm{m}-$ thick cryostat sections of perfused rat tissues according to the modified protocol of Higgins and Wilson (1987) as described by Forss-Petter et al. (1989). For autoradiography, slides were coated with Ilford K-5 emulsion diluted $1: 1$ with water and incubated for $5-21 \mathrm{~d}$.

Immunohistochemistry. After perfusion fixation of normal and colchicine-pretreated ( $50 \mu \mathrm{g}$, i.c.v., injected $48-72 \mathrm{hr}$ before fixation) adult rats, $40 \mu \mathrm{m}$ cryostat sections of brain, prepared as described in Bloom et al. (1985), were incubated overnight at $4^{\circ} \mathrm{C}$ in a fresh solution of PBS containing $1 \%$ BSA, $0.3 \%$ Iriton X-100, and a 1:1000 dilution of antisera. The sections were then washed in PBS. The primary antibody was detected on the tissue sections by a commercial avidin-biotin complex (Vectastain ABC, Vector Labs, Burlingame, CA), with horseradish peroxidase as the marker and diaminobenzidine as the chromophore. At the end of processing, sections were briefly exposed to $0.1 \% \mathrm{OsO}_{4}$, and counterstained with cresyl violet to enhance cellular morphology.

Samples for electron microscopy were exclusively from normal untreated rats prepared as described (Bloom et al., 1985), with the following modifications. The avidin-biotin complex (see above) was used to detect the primary antibody. Primary antibody, biotinylated secondary antibody, and avidin-biotin complex incubations were extended to $12-24$ $\mathrm{hr}$ at $4^{\circ} \mathrm{C}$. The horseradish peroxidase reaction employing diaminobenzidine as the chromophore, and subsequent processing of samples for electron microscopy were as described (Bloom et al., 1985). Ultrathin sections, mounted on 200 mesh copper grids, were stained with lead citrate and viewed in a Zeiss EM 10B microscope.

Bacterial expression of $1 G 5$ and $\alpha$ CaMKII. Overexpression of "fusionless" 1 G5 and $\alpha$ CaMKII was accomplished by directionally subcloning 1 G5 and $\alpha$ CaMKII cDNA (Bulleit et al., 1988) into pRK172 (McLeod et al., 1987), which had been digested with Ndel and EcoRI, to produce clones pRK-1G5 and pRK- $\alpha$ CaMKII. To obtain compatible sticky ends for proper in-frame subcioning of the $1 G 5$ and $\alpha \mathrm{CaMPK}$ coding region, we performed selective amplification by PCR, using conditions suggested by Perkin Elmer/Cetus to decrease infidelity of Taq polymerase: $200 \mu \mathrm{M}$ dNTPs and $1.5 \mathrm{~mm} \mathrm{MgCl}_{2}$, AmpliTAQ in the incubation mixture, annealing at $55^{\circ} \mathrm{C}$ with 20 cycles. For $1 \mathrm{G} 5$, the primer containing the initiation codon (ATG) and NdeI site was $5^{\prime}$ GCATCATATGCCGTTTGGTTGTGTGACTCTG-3'. For $\alpha$ CaMKII the primer was 5'-GCGGAGCCCATATGGCTACCATCACCTGCACC- $3^{\prime}$. The primer containing the complementary sequences of the stop codon (TGA) and EcoRI site for 1G5 was 5'-GCATGAATTCTCAGCTTGTCTCCACCCTCTG-3'; for $\alpha$ CaMKII the primer was 5-GCGGAGCCGAATTCTCAATGGGGCAGGACGGAGGG-3'. The $1 G 5$ and $\alpha$ CaMKII PCR products were subcloned into pRK172, transformed into DH5 (GIBCO/Bethesda Research Labs), and plated as described (Maniatis et al., 1982). Colonies were picked and grown overnight in LB broth with $50 \mu \mathrm{g} / \mathrm{ml}$ ampicillin. Subclones containing the 1 G5 and $\alpha$ CaMPK cDNA inserts were transformed in to the BL21(DE3) (Studier et al., 1990) strain for overexpression. The nucleotide sequence of the 1 G5 subclone was verified across the entire open reading frame (ORF). Expression of $1 \mathrm{G} 5$ was induced when cells reached $\mathrm{OD}_{600}=0.6$ by adding a final concentration of $1 \mathrm{~mm}$ isopropyl- $\beta$-D-thiogalactopyranoside (IPTG), followed by an additional $2 \mathrm{hr}$ of shaking at $32^{\circ} \mathrm{C}$. As a negative control, the pRK172 vector with no insert was also transformed into BL21(DE3) and subsequently induced. For immunoblot analysis, bacteria were spun down and analyzed on SDS-PAGE gels as described hy Sambrook et al. (1989).

Calcium-dependent calmodulin binding of IG5. Several independent bacterial colonies harboring either pRK-1G5 or pRK- $\alpha$ CaMKII were each added to $100 \mathrm{ml}$ of $\mathrm{LB}$ and $100 \mu \mathrm{g} / \mathrm{ml}$ ampicillin. Cells were induced at $\mathrm{OD}_{600}$ of 0.6 with $1 \mathrm{~mm}$ IPTG, and incubated for $2 \mathrm{hr}$. Cells were spun down, washed twice with ice-cold $10 \mathrm{~mm}$ Tris $\mathrm{pH} 8.0$, and resuspended in $5 \mathrm{ml}$ of homogenization buffer $[10 \mathrm{~mm}$ Tris, pH $7.5 ; 1 \mathrm{~mm}$ EDTA, pH 8.0; 1 mm EGTA, pH 8.0; 0.5 mm dithiothreitol (DTT), 0.1 mM phenylmethylsulfonyl fluoride]. The resuspended cells were then put through one cycle of freeze/thaw (liquid nitrogen followed by $37^{\circ} \mathrm{C}$ ) and sonicated until the solution was no longer viscous. Cell debris was removed by centrifugation and the homogenate volume was measured in order to add $\mathrm{CaCl}_{2}$ to a final concentration of $5 \mathrm{~mm}$. The homogenate was applied to a $17 \mathrm{ml}$ calmodulin-sepharose 4B (Pharmacia) column, washed with $100 \mathrm{ml}$ of homogenate buffer containing $5 \mathrm{mM} \mathrm{CaCl}_{2} ; 1 \mathrm{G} 5$ was then eluted from the column with $100 \mathrm{ml}$ of homogenate buffer containing $2 \mathrm{~mm}$ EGTA. Fractions $(6 \mathrm{ml})$ were collected and analyzed by SDS-polyacrylamide gel electrophoresis.

Protein kinase assay. 1G5- and $\alpha$ CaMKII-containing bacterial extracts or column fractions were assayed for their ability to phosphorylate syntide-2 peptide as previously described (IIashimoto and Soderling, 1987; Ohsake et al., 1990). Briefly, $5 \mu$ l of extract or column fraction was added to $45 \mu$ l of the following solution: $25 \mathrm{~mm}$ HEPES pH 8.0,1 $\mathrm{mm} \mathrm{CaCl}_{2}, 4 \mathrm{~mm} \mathrm{Mg}\left(\mathrm{CH}_{3} \mathrm{COOH}\right)_{2}, 0.25 \mathrm{~mm}$ DTT, $26 \mu \mathrm{M}$ syntide- 2 peptide, $2.4 \mu \mathrm{M}$ calmodulin, $15 \mu \mathrm{M}$ ATP, and $0.5 \mu \mathrm{M}{ }^{32} \mathrm{P}-\mathrm{ATP}(150 \mathrm{mCi} /$ $\mathrm{ml}, 6000 \mathrm{Ci} / \mathrm{mmol}$; New England Nuclear). The reaction was incubated at $30^{\circ} \mathrm{C}$ for $60 \mathrm{sec}$ and then stopped by the addition of $8 \mu 1$ of $0.5 \mathrm{M}$ 
EDTA. The reaction was then spotted on phosphocellulose disks, washed with $75 \mathrm{~mm}$ phosphoric acid three times at $2 \mathrm{~min}$ intervals, air dried, and counted by liquid scintillation.

\section{Results}

Cloning of a cortex-enriched $m R N A$

We previously isolated clone $6 \mathrm{E} 9$ from a monkey cerebral cortex cDNA library by screening with a monkey cortex-minus-cerebellum subtracted cDNA probe (Travis and Sutcliffe, 1988; Bernal et al., 1990). The cDNA clone hybridized to a $3.6 \mathrm{~kb}$ monkey cortex polyA ${ }^{+}$RNA, not detectable in liver or cerebellum but present in several other brain regions, and also to a human polyA $^{+}$RNA of the same size (Bernal et al., 1990). Clone 6E9 was used as a hybridization probe for screening a rat hypothalamus cDNA library and apparently full-length clones were isolated. The rat homologs, called $1 \mathrm{G} 5$ clones, could be separated by length into two groups. The complete nucleotide sequence of one member of each group was determined on both strands (composite shown in Fig. 1). One sequence was 3636 bp in length (exclusive of polyA); the second, $2986 \mathrm{bp}$. The shorter sequence extended $19 \mathrm{bp}$ farther at the $5^{\prime}$ end and the two sequences were identical in their 2967 bp overlap. The shorter sequence contained the consensus polyA addition sequence AATAAA (Proudfoot and Brownlee, 1976) 18 nucleotides from its $3^{\prime}$ end, suggesting that the two groups of cDNA clones represent two pools of $\mathrm{mRNA}$ that are derived by alternative polyadenylation of the transcripts of a single rat gene. This interpretation is consistent with the observation that a single 1G5-hybridizing band was detected in Southern blots prepared with rat EcoRI-digested genomic DNA (data not shown). The single mouse homolog of the $1 \mathrm{G} 5$ gene has been mapped by RFLP analysis of recombinant inbred lines to chromosome 9 in the vicinity of the tip locus (PED, JGS, W. Frankel, unpublished observations).

To establish that nearly full-length cDNA clones had indeed been isolated, we performed anchored PCR (Frohman et al., 1988 ), using rat brain CDNA as template and an oligonucleotide complementary to nucleotides $478-501$ as primer, cloned the products, and isolated individual clones for sequence analysis. The sequences of the six longest cloned products matched the composite sequence (with occasional single-base differences presumably introduced by PCR) and extended 12-58 nucleotides farther $5^{\prime}$ than the cDNA sequence, suggesting that our composite sequence represents nearly full-length 1G5 mRNAs or, possibly, that $1 \mathrm{G} 5$ transcription initiates at multiple clustered sites. The composite of the two mRNA sequences contains a single, common long ORF. A 5' untranslated region of 132 nucleotides precedes the 1512 nucleotide ORF, which is followed by $3^{\prime}$ untranslated regions of 2011 or 1342 nucleotides.

\section{$1 G 5$ resembles Ser/Thr protein kinases}

The encoded putative protein of 504 amino acids, which has a predicted unmodified molecular weight of 54,105 , was used to search the Genbank and Swiss-prot databases. The amino terminal region (residues $1-325$ ) exhibited a high degree of identity with the catalytic and calmodulin-binding domains of CaMKII, a scrinc/thrconinc kinase (Bennett and Kennedy, 1987). Residues 326-374 exhibit general similarity to the glycine/alanine/ serine-rich domain near the carboxy terminus of the shaggy gene product of Drosophila melanogaster, also a Ser/Thr protein kinase (Bourouis et al., 1990). The carboxy-terminal region of the IG5 sequence did not exhibit any striking similarities to proteins in the databases. A notable feature of the carboxy-terminal region is the eight-residue motif DR/GSA/VTPAT, which occurs seven times in tandem, with echoes occurring several times thereafter. This region could be related to PEST sequences, thought to confer short half-lives to proteins that contain them (Rogers et al., 1986). There is a 19-residue hydrophobic region (residues 203-221) that could span a membrane and a 32-residue uncharged region (340-371) that is not particularly hydrophobic. There are no putative sites for $N$-glycosylation.

The amino acid sequences of the catalytic domains of protein kinases strongly resemble one another, and 206 kinase sequences (as of July 1992) have been compiled into a database (Hanks and Quinn, 1991; Hunter, 1991). We compared residues 1-325 of $1 \mathrm{G} 5$ to the members of the compiled database and found greatest sequence identity $(42 \%)$ with a putative serine kinase from human HeLa cell cDNA (J. R. Woodgett, unpublished observations), the subunits of CaMKII ( $\alpha=39 \% ; \beta=38 \%$ and $38 \%$ ), the $\gamma$-subunit of phosphorylase kinase (35\%), and two homologs of CaMKII from S. cerevisiae (CMK2 = 35\%; CMK1 $=34 \%$ ). Alignment of the amino termini of $1 \mathrm{G} 5$ and $\alpha \mathrm{CaMKII}$ is shown in Figure 2 and considered in detail in the Discussion.

Immediately downstream from the catalytic domain of CaMKII is its calmodulin-binding domain. 1G5 contains a similar sequence (ARAKWKKAVRVTTLMKR, residues 309-325) in the same relative position (Fig. 2). Significantly, the $W-X_{11}-R$ conserved among other known calmodulin-binding kinases (Bagchi et al., 1992) is present. 1G5 does not contain a consensus sequence (RXXS/T) similar to the autophosphorylation site located between the catalytic and calmodulin-binding domains in CaMKII (Miller et al., 1988). Cumulatively, these sequence comparisons suggest the hypothesis that $1 \mathrm{G} 5$ might have calmodulin-binding and/or protein-kinase properties.

\section{Spatial and temporal restriction of $1 G 5 \mathrm{mRNA}$}

A probe corresponding to nucleotides 1191-1524 of the rat $1 \mathrm{G} 5$ cDNA sequence was used in a Northern blot hybridization study to examine polyA ${ }^{+}$RNA isolated from several rat peripheral tissues, from several regions of rat brain, and from whole brains of embryonic and early postnatal rats of several ages. The probe detccted two RNAs of approximatcly 3.2 and $3.8 \mathrm{~kb}$ (ratio of $5: 1$ ) present in brain (Fig. $3 A$ ) and eye (data not shown), but not detected in liver or kidney (Fig. $3 A$ ), or spleen, thymus, bladder, aorta, lung, intestine, esophagus, stomach, skeletal muscle, heart, diaphragm, uterus, tail, ear, skin, submaxillary gland, prostate, epididymis, placenta, pancreas, ovary, testis, adrenal gland, parathyroid gland, thyroid gland, pineal gland, pituitary, or sciatic nerve (data not shown). Within the brain of adult rats, the RNAs were most prevalent in hippocampus, caudate nucleus, cortex, hypothalamus, olfactory bulb, and midbrain, were faintly detected in pons, brainstem, and spinal cord, but were not detected in cerebellum (Fig. 3A). These results are similar to those obtained with the monkey homolog $6 \mathrm{E} 9$ (Bernal et al., 1990). The RNAs were first faintly detectable in the brains of developing rats at embryonic day 16 (E16), but accumulation was primarily postnatal with maximal steady state levels reached at postnatal day 10 (P10; Fig. $3 B$ ).

A portion of the 1G5 cDNA insert (nucleotides 1191-1524) was transferred to a transcription vector and riboprobes corresponding to 1 G5 sense and antisense were generated and used for in situ hybridization studies on rat brain sections. Only lowlevel background hybridization was detected with the sense probe. 


\begin{tabular}{|c|c|c|c|c|c|c|}
\hline \multirow{3}{*}{$\begin{array}{l}\text { CAMII } \\
1 \text { G5 }\end{array}$} & $I$ & & II & III & \multicolumn{2}{|r|}{$V$} \\
\hline & NQPSEVTDRYDLGQVVKTEEFCEIFR & & KTTGKLHTCKKFQKR & DGRKVRKAAKNE IGILKI & KHPNILQLVDVFVTR & -KEYF IFLELATGREVFDWILDQGY \\
\hline & $\star * * \quad *$ & & * $\quad$ * $* \quad$ * & 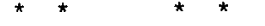 & 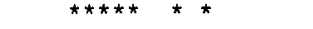 & $\star \star * * \quad * \quad * * * * \quad * \quad * \quad *$ \\
\hline & $V I A$ & & $V I B$ & VII & VIII & \\
\hline CAMI I & YSEADASHCIQQILEAVLHCHQM & GVVHRI & LXPENLLLASKLKGA & AVKLADFGLAIEVEGE & QQAWFGFAGTPGYLSPEVL & \\
\hline $1 \mathrm{G} 5$ & YSERDTSNVVROVLEAVAYLHSL & KIVHRI & LKLENLVYYNRLKNS & KIVISDFHLAKLENGL & ---IKEPCGTPEYLAPEVV & \\
\hline & 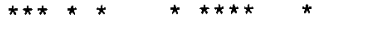 & $\star \star \star *$ & $* * * * * \quad * *$ & 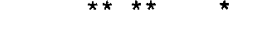 & & \\
\hline & $I X$ & & & $x$ & 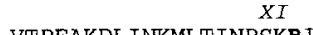 & \\
\hline $\begin{array}{l}\text { CAMI I } \\
1 \mathrm{G5}\end{array}$ & RKDPYGKPVDLWACGVILY ILLVGYP & PFWD & ---ED-----QHRLY & QIKAGAYDF PSPEWDT & VT PEAKDLINKMLT INPSKR I & TAAEALKHPWI \\
\hline $1 \mathrm{GS}$ & GRQRYGRPVDCWAIGVIMYILLSGNP & PFYE & $\underset{\star}{\text { EVEEDDYENHDKNLF }}$ & KILAGDYEFDSPYWDD & 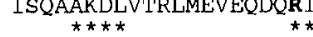 & TAEEAISHEWI \\
\hline & & Bindi & Domain & & & \\
\hline CAMII & SHRSTVAS-CMHRQETVDCLKKFNA & ARRKLK & AILTTMMTAATR & & & \\
\hline 165 & $\underset{\star}{\mathrm{S}-- \text { GNAASDKNIKDGVCAO }}$ & 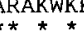 & AVRVTTLMKR & & & \\
\hline
\end{tabular}

Figure 2. Comparison of the conserved protein kinase subdomains of $\alpha$ CaMKII (CAMII; residues 13-314) to the amino terminus (residues 15325 ) of $1 \mathrm{G} 5$. Gaps in the amino acid sequences, shown by dashes, were introduced by eye to optimize the alignment. The sequences are contiguous, but are broken into segments corresponding to the 12 protein kinase subdomains and the calmodulin-binding domain. Asterisks indicate amino acid identities. Residues shown in boldface are conserved among known protein kinases.

The antisense probe hybridized (Table 1) to discrete neuronal groupings in many regions of the brain including some regions in which the mRNA had not been interpreted as abundant by Northern blot analysis. Thus, in keeping with the Northern blot data, there was a generally high hybridization signal throughout cortical regions, especially the frontal, cingulate, and entorhinal cortices. In addition, strong hybridization was detected over neuronal groups within specific structures immediately adjacent to the entorhinal cortex, such as the central nucleus of the amygdala (Fig. $4 A, B$ ), the medial septal nucleus, and the bed nucleus of the stria terminalis, with more moderate hybridization detected over the caudate nucleus. High-intensity hybridization was also detected over subsets of neurons occupying proportionately smaller volumes of regions that were not noted in the Northern blot survey: the external cortex of the inferior colliculus, several pontine nuclei, the trigeminal sensory system throughout the spinal and medullary zones (Fig. 4C,D), the arcuate and premammillary nuclei of the hypothalamus, and in various thalamic nuclei. More moderate but definitive hybridization was observed over the CA1 and CA3 fields of hippocampus and the adjaccnt parahippocampal cortex, but not over neurons of the dentate gyrus. A less definitive, low-level signal was observed over the cerebellum. It was not concentrated over any particular cell type and, given the results from Northern blotting and the immunochemical analyses described below, is presumed to be background.

\section{Detection of the $1 G 5$ protein}

To demonstrate that the $1 G 5$ protein exists in vivo and to learn about its anatomical and subcellular distribution, we generated antisera to synthetic peptides corresponding to nonoverlapping regions of the $1 G 5$ amino acid sequence. The antisera were shown to react with bacterially expressed 1G5 (see below for more detail regarding bacterial expression) and were used in Western protein immunoblotting experiments to examine tissue extracts. The antisera to each of two nonoverlapping peptides, designated 1G5-4 and 1G5-5, reacted with a band in wholebrain extracts that migrated at $M_{r} 72-80 \mathrm{kDa}$ (depending upon the acrylamide gel percentage), the same migration as the bacterially expressed $1 G 5$ protein (Fig. $5 c$ ). Figure 5 shows data with 1G5-5 antisera; comparable data were obtained with $1 \mathrm{G} 5-4$ antisera (not shown). Immunoreactivity against the $72-80 \mathrm{kDa}$ target was completely blocked by preincubating the antisera with their respective synthetic peptides (data not shown).

The immunoreactive target was detected in extracts from cortex, hypothalamus, medulla, retina, and olfactory bulb, and at higher levels in hippocampus and caudatc nuclcus, but was not detected in extracts from spinal cord, thalamus, pons, or cerebellum (Fig. $5 b$ ). The protein was not detected in extracts from liver or kidney (Fig. $5 b$ ), or muscle, thymus, spleen, uterus, or testes (data not shown). In extracts from brains of developing rats, the protein was first faintly detectable at E20, and accumulated during postnatal development, attaining maximal levels at P10 (Fig. 5c). Incubation of brain extracts with endoglycosidase $F$, an enzyme that removes $N$-linked glycans from glycoproteins, did not affect the mobility of the immunoreactive band (data not shown), consistent with the absence of consensus $N$-glycosylation motifs in the $1 G 5$ sequence.

Cumulatively, these data show that the detected polypeptide represents the protein product of the $1 \mathrm{G} 5$ mRNAs. Moreover, there is a good match between the RNA and immunoblot data for the regional distribution of $1 \mathrm{G} 5$ in the brain.

\section{Association with neurite membranes and vesicles}

Only one of the two Western-reactive antisera (1G5-5) was found to be suitable for immunohistochemical analyses. Its reactivity was, in almost all cases, blockable by preincubation with cognate synthetic peptide and only blockable reactivity is reported here. The antiserum, as observed by light microscopy, reacted with structures in all regions of the brain except the cerebellum (Fig. 6). Reactivity was predominantly observed in neurites, with fainter reactivity detected over cell soma. The overall distribution of immunoreactivity (Table 1, Fig. 6A) was generally consistent with the distribution of the $1 \mathrm{G} 5 \mathrm{mRNA}$ detected by in situ hybridization, although no immunoreactivity was detected in the arcuate nucleus or premammillary nuclei. Dense 1G5 immunoreactivity was observed in dendritic structures in several regions of the cerebral cortex including the cingulate (Fig. 6B) and the external cortex of the inferior colliculus (Fig. $6 C$ ), in fascicles of axons in the fimbria at the lateral boundary of the hippocampal formation (Fig. 6D), in the bed nucleus of the stria terminalis (Fig. $6 E$ ), and in the spinal trigeminal tract (Fig. $6 F$ ), as well as both fibers and perikarya in the dorsal horn 


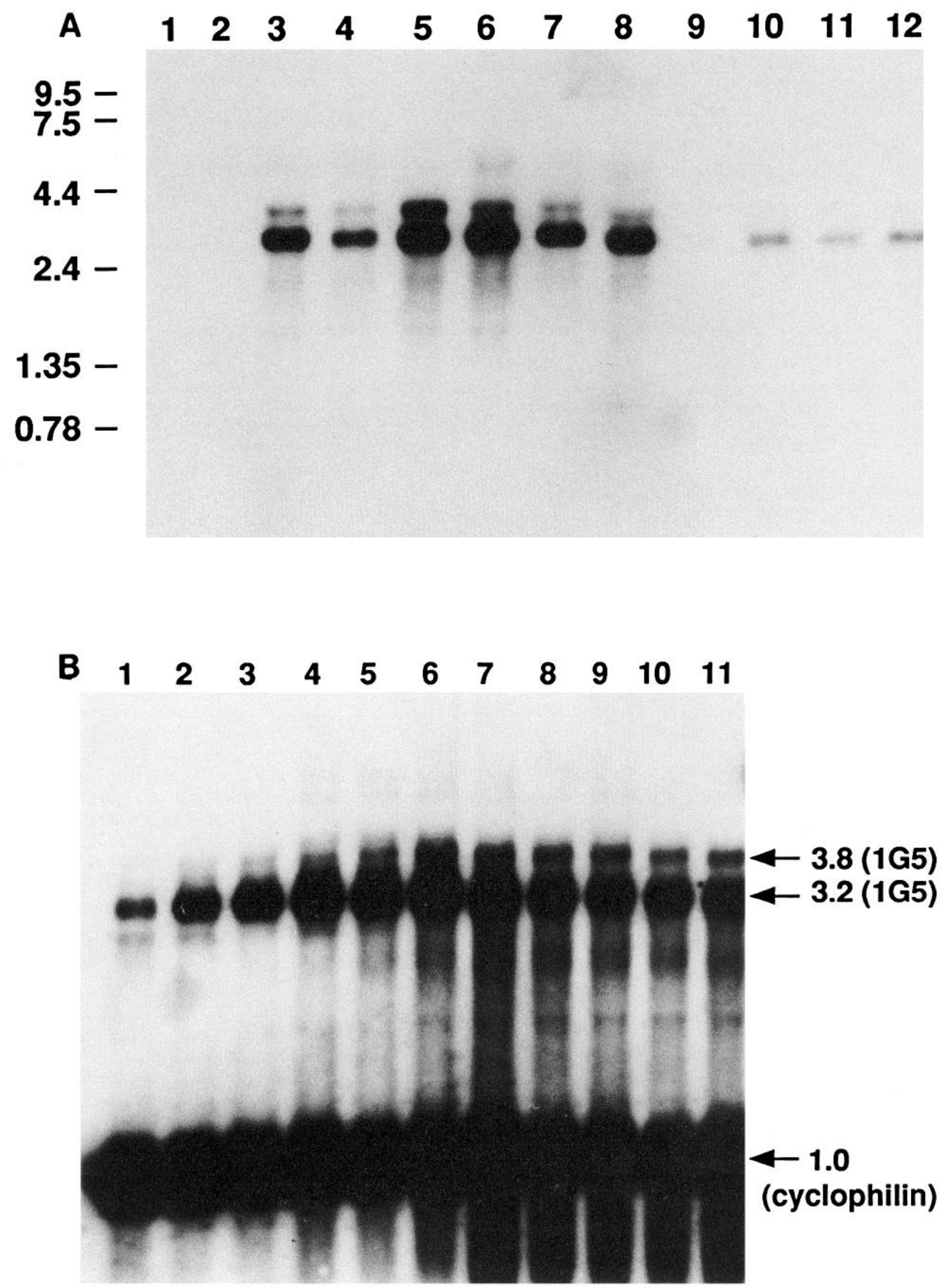

Figure 3. Northern blot detection of 1G5 mRNAs. A, PolyA-enriched RNA from rat kidney (1), liver (2), olfactory bulb (3), cerebral cortex (4), caudate nucleus (5), hippocampus (6), hypothalamus (7), midbrain (8), cerebellum (9), pons (10), medulla (11), and spinal cord (12). B, PolyAenriched RNA from whole brains of developing rats aged E16 (1), E18 (2), E20 (3), P1 (4), P5 (5), P10 (6), P15 (7), P20 (8), P25 (9), P30 (10), and adult (11). mRNA was separated by electrophoresis and probed with 1G5 cDNA or cyclophilin cDNA as a positive control. The mobility of size markers is indicated in the margin. 

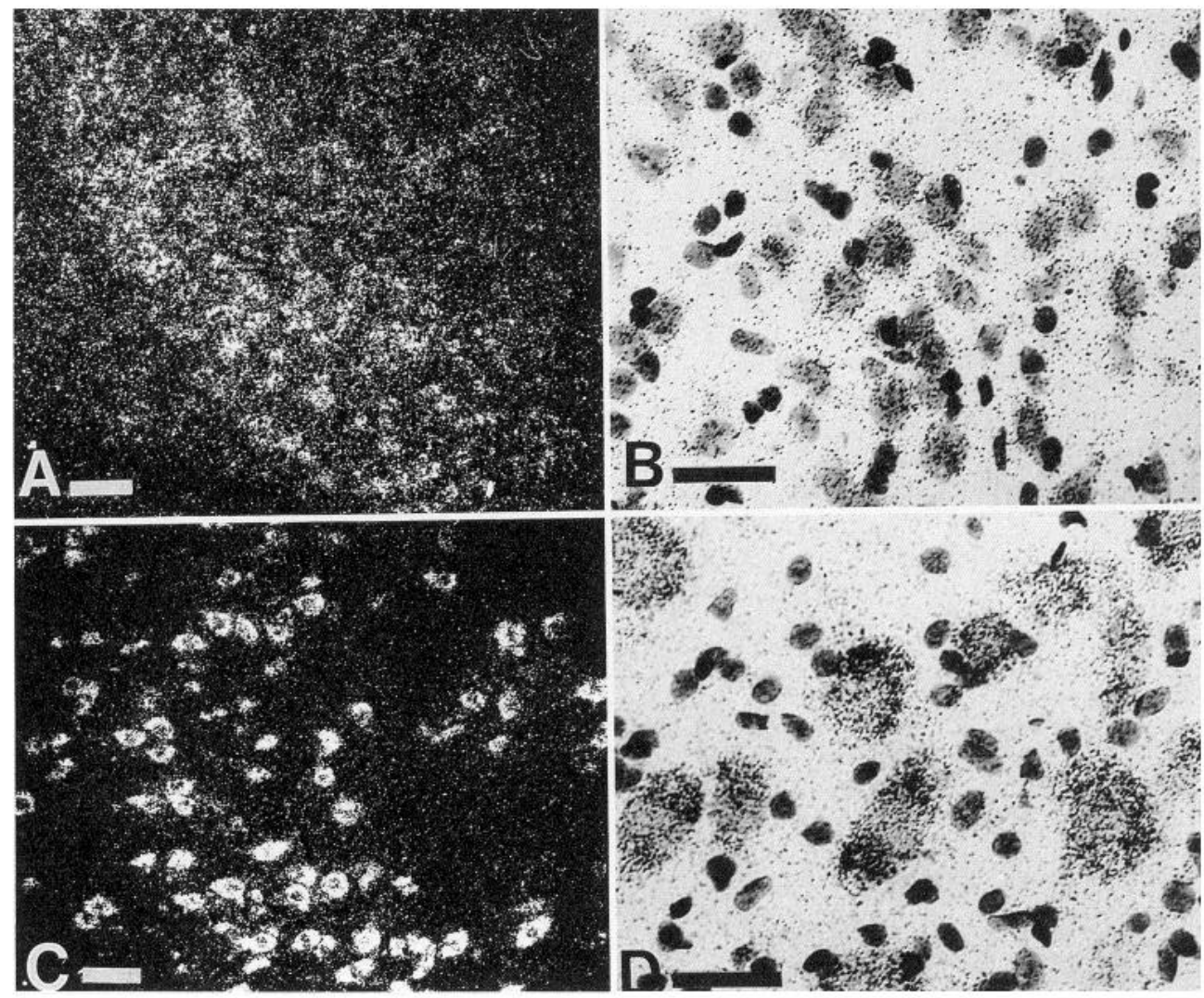

Figure 4. In situ hybridization to 1G5 mRNA: autoradiographic localization of ${ }^{35} \mathrm{~S}$-labeled riboprobe in tissue sections of the central nucleus of the amygdala $(A, B)$ and the spinal trigeminal nucleus $(C, D)$. For each structure, the micrographs demonstrate grain localizations at low magnification with darkfield illumination $(A, C)$ and at higher magnification by bright-field illumination counterstained with Richardson's stain $(B, D)$. A high density of grains over large neurons is seen in both darkfield views, while the bright-field microscopy shows clusters of grains that are more dense over the cytoplasm of these neurons than their smaller darkly stained nuclei. No autoradiographic label is seen surrounding the nuclei of presumptive astrocytes in the surrounding neuropil. Scale bars: $A$ and $C$, $50 \mu \mathrm{m} ; B$ and $D, 25 \mu \mathrm{m}$. of the spinal cord and several other pontine and thalamic nuclei (Table 1).

High levels of $1 \mathrm{G} 5$ were detected in cortical regions, by both in situ hybridization and immunocytochemistry, the highest being in the cingulate and entorhinal cortical regions, but only slightly lesser amounts in other cortical regions. Because of the difficulty of immunocytochemical detection of definitive perikaryal profiles against the dense background of vertically oriented dendritic profiles in the cortical regions, we used colchicine to reduce centrifugal transport in an effort to enhance perikaryal immunoreactivity. This treatment gave slight enhancement to perikarya that were already detectable in the diencephalic, hindbrain, and spinal regions, but did not conclusively enhance perikarya in cortical regions.

Electron microscopic visualization of brains of non-colchicine-treated rats revealed that both cell soma and processes (dendrites and axons) contained 1G5-immunoreactive material, including soma in cortical fields (Fig. 7). Immunoreactivity was abundant throughout the dendritic trees of neurons in each of the regions where immunoreactivity had been detected by light microscopy. Within the perikarya and larger dendritic branches, immunoreactivity was restricted to the perimeter of the structural element, immediately beneath the plasma membrane (shown in entorhinal cortex, Fig. 7A). In smaller dendrites, immunoreactivity was associated with microtubules and with small smooth endoplasmic reticular vesicles (shown in cingulate cortex, Fig. $7 B$ ). In dendritic spines, immunoreactivity was associated with the postsynaptic membrane specializations as well as other sites (shown in cingulate cortex, Fig. 7C). In axon terminals, immunoreactivity was associated with synaptic vesicles, including those clustered near the plasma membrane op- posite postsynaptic specializations (shown in cingulate cortex, Fig. 7D). Although $1 \mathrm{G} 5$ immunoreactivity was detected in both dendrites and in axons, we observed no cases in which there was contact between the immunoreactive axons and dendrites. Anatomical observations will be reported in more detail separately.

\section{Calcium-dependent calmodulin binding}

To test hypotheses about 1G5's biochemical function, we used PCR to tailor the 1G5 ORF for cloning in a bacterial expression vector and produced clone pRK-1G5, which was expected to express the full-length $1 \mathrm{G} 5$ protein under control of the lac promoter. Bacteria transformed with pRK-1G5 were treated with the lac operon transcriptional inducer IPTG, and protein extracts were prepared and examined by SDS-PAGE. Extracts from IPTG-induced bacteria contained a protein that migrated at $72-80 \mathrm{kDa}$, which was not detectable in nontransformed bacteria (induced or uninduced) or transformed, uninduced bacteria. The expressed protein was reactive with $1 G 5$ anti-peptide sera, whereas there was no reactive band in IPTG-induced bacteria that received the vector with no 1 G5 sequences (Fig. $5 a$ ).

A bacterial extract containing the expressed $1 \mathrm{G} 5$ protein was applied in the presence of $5 \mathrm{~mm}$ calcium to a calmodulin-sepharose column. The column was washed extensively with a calcium-containing buffer, and then with a buffer containing EGTA but no calcium. Fractions were collected and analyzed by electrophoresis (Fig. 8). Some of the 1 G5 protein eluted with the flow-through material, but none with the calcium washes. The remaining $1 \mathrm{G} 5$ eluted after EGTA treatment. An extract from bacteria containing pRK- $\alpha$ CaMKII, a clone expressing $\alpha$ CaMKII, was chromatographed in parallel, and $\alpha$ CaMKII ac- 


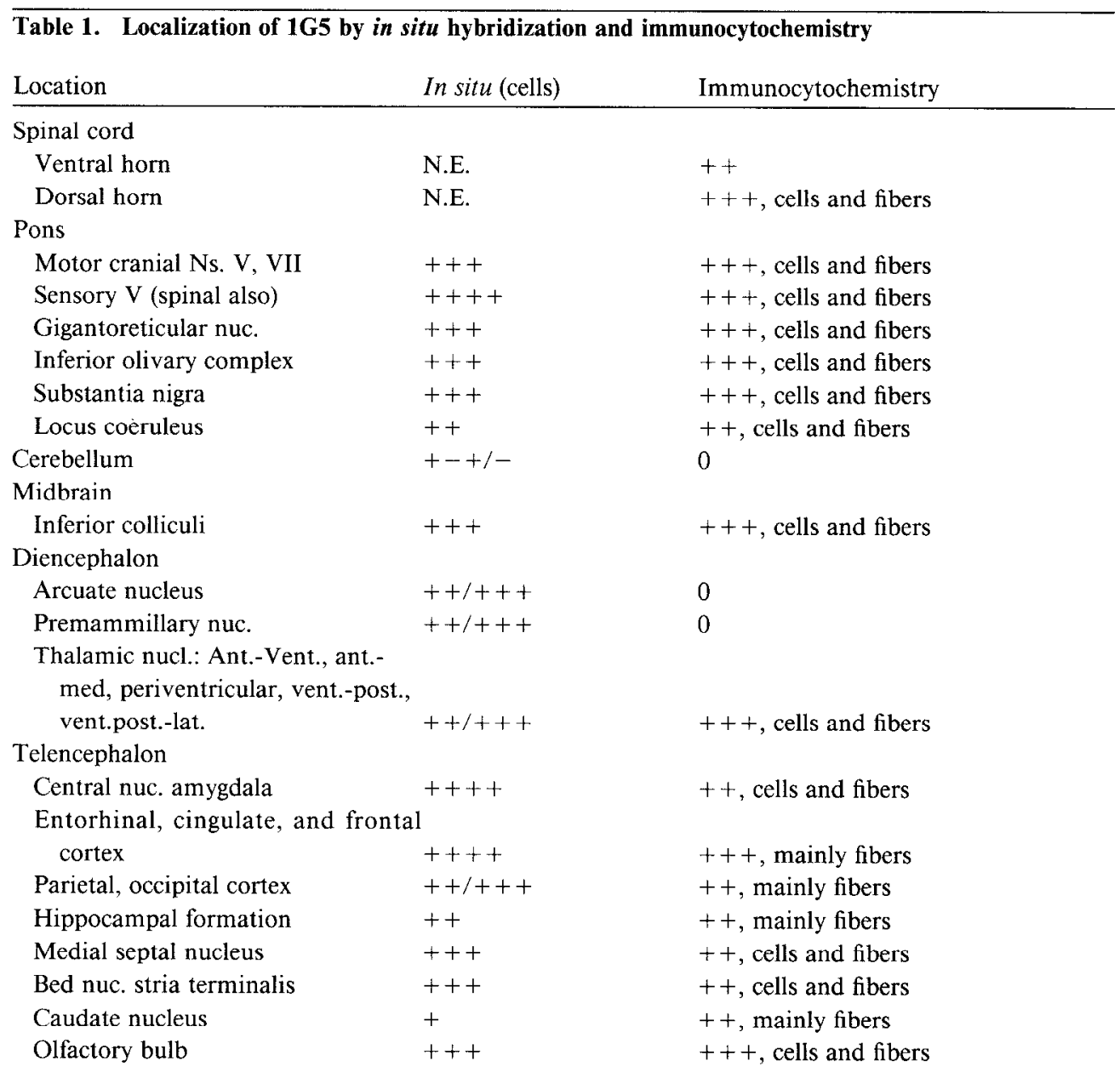

This table indicates the density of autoradiographic grains for in situ hybridizations of neuronal perikarya and their dendrites and the intensity of immunocytochemical reactivity for cells and fibers in specific macroscopic brain regions. For each set of regional estimates, density of grains or intensity of immunoreactivity was based upon the number of reactive elements, the clustering of grains, or the density of the immunoperoxidase end product and graded on a relative four-point scale, from + (minimum detectable reactivity) to ++++ , using the spinal trigeminal nucleus as the maximum density for both indices. N.E., not examined; Ns., nerves; nuc., nuclei; ant., anterior; vent, = ventral; post., posterior; lat., lateral.

tivity eluted from the calmodulin column in the samc fractions as 1 G5 (data not shown). Thus, $1 \mathrm{G} 5$ binds to calmodulin when calcium is present, but not in its absence.

A bacterial extract containing recombinantly expressed 1G5 protein and, as a positive control, an extract containing the $\alpha$-subunit of CaMKII, recombinantly expressed by the same method, were incubated with the synthetic peptide CaMKII/ protein kinase $C$ substrate syntide-2 (Hashimoto and Soderling, 1987), in the presence of calmodulin and ${ }^{32}$ P-ATP. After the reaction, the syntide was applied to phosphocellulose and labeled syntide-2 was measured by liquid scintillation. The syntide- 2 peptide was labeled by $\alpha$-CaMKII but not by 1 G 5 (data not shown). Comparable results were obtained with the 1G5-containing and $\alpha \mathrm{CaMKII-containing} \mathrm{fractions} \mathrm{from} \mathrm{the}$ calmodulin-sepharose column (data not shown). No peptide labeling was detected for either 1 G5 or CaMKII when either calcium, calmodulin, or both were omitted from the reaction.

\section{Discussion}

By analyzing clones of $\mathrm{mRNAs}$ enriched in cerebral cortex over cerebellum, isolated by a procedure using subtractive hybridization, we have learned about a 504-residue protein related in sequence to protein kinases. The 1G5 protein, which is first detected at E20 and thus accumulates predominantly during postnatal development, binds to calmodulin in the presence of calcium. It is detected only in the CNS, is absent from cerebellum, but is detected in most other brain regions, especially regions of the cortex. The protein is predominantly detected in association with the plasma membrane of soma and in neurites, both axons and dendrites, and is frequently observed in active zones, usually associated with vesicle-like structures. Its sequence suggests that $1 \mathrm{G} 5$ may be membrane associated. In a previous study (Bernal et al., 1990), we showed that the concentration of the human 1G5-homologous mRNA in frontal cortex is greatly reduced relative to normal controls in patients with Alzheimer's disease.

Hunter and colleagues have recognized 12 subdomains within the catalytic domains conserved among all known protein kinases (Hanks et al., 1988; Hunter, 1991). The catalytic domains are not conserved uniformly, but rather consist of alternating regions of high and low conservation: subdomains I, II, III, VIB, VII, VIII, IX, and XI contain either nearly or totally invariant residues, whereas subdomains $I V, V$, VIA, and $X$ are only structurally conserved. In Figure 2 we compare the sequence of the 


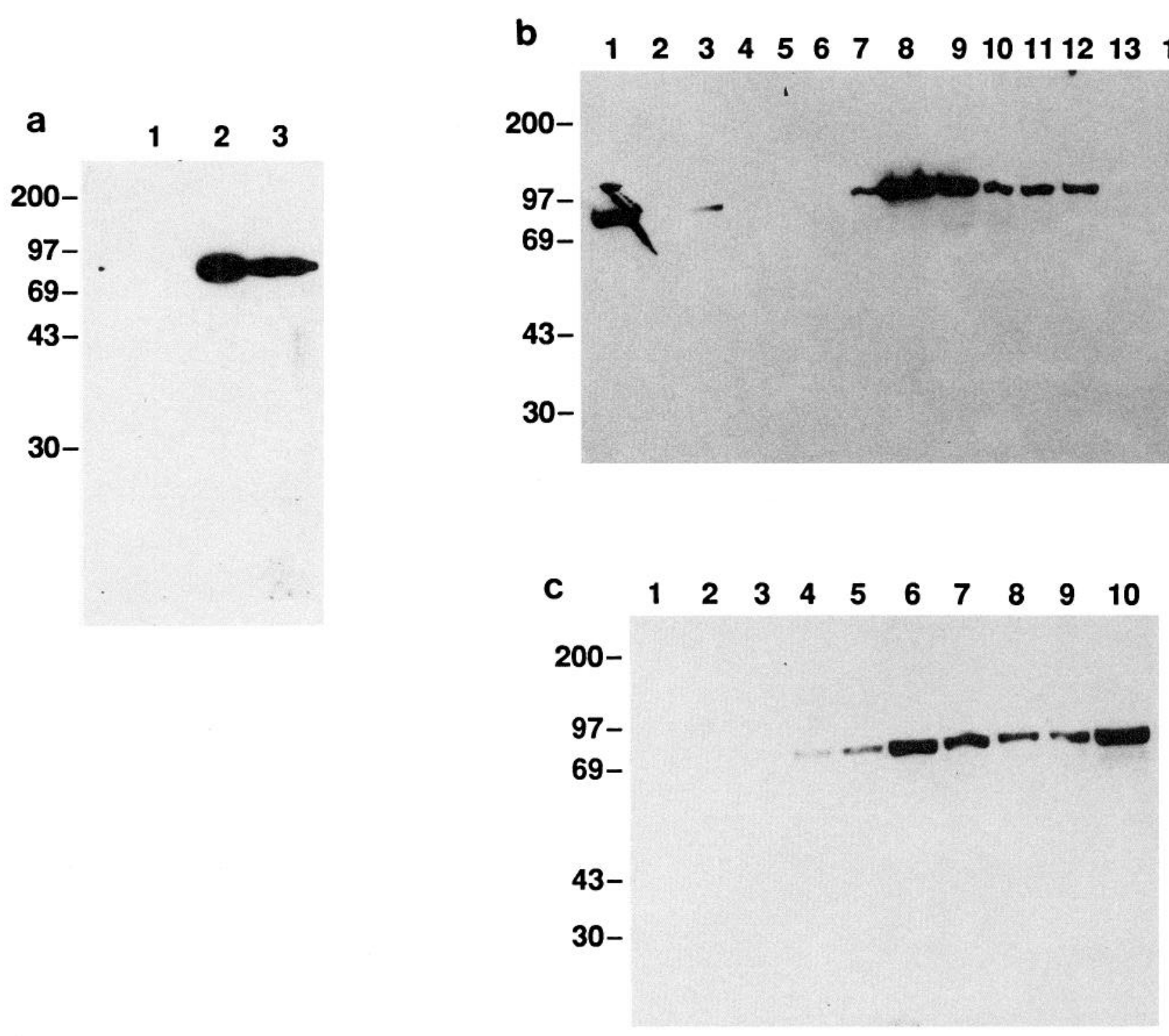

Figure 5. Westem blot immunodetection of 1 G5 protein. $a$, Extracts from bacteria containing the parent vector pRK172 with no cDNA insert induced with IPTG (1), bacteria containing pRK-1G5 plasmid induced with IPTG (2), and rat brain (3). $b$, Extracts from rat brain (1), spinal cord (2), medulla (3), pons (4), cerebellum (5), thalamus (6), hypothalamus (7), hippocampus (8), caudate nucleus (9), cortex (10), olfactory bulb (11), retina (12), kidney (13), and liver (14). c, Extracts from whole brains of developing rats aged E16 (1), E18 (2), E20 (3), P1 (4), P5 (5), P10 (6), P15 (7), P20 (8), P25 (9), and adult (10). For all panels, the migration of molecular weight size markers (in kDa) is indicated at the left. Each blot was reacted with antisera directed against peptide $1 \mathrm{G} 5-5$.

amino terminal region of $1 \mathrm{G} 5$ to the 12 subdomains of $\alpha$ CaMKII. Most of the subdomains and invariant residues (11 of the 15 invariant or nearly invariant residues of known protein kinases) appear in the $1 \mathrm{G} 5$ sequence, whereas some do not. Furthermore, $1 \mathrm{G} 5$ contains significant amino acid sequence identity with $\alpha$ CaMKII in the structurally conserved domains (subdomain IV $=47 \%, \mathrm{~V}=40 \%$, VIA $=48 \%$, and $\mathrm{X}=50 \%$, excluding gaps introduced to maintain alignment).

Analysis of sequence conservation within protein Ser/Thr or protein tyrosine kinases has suggested (Hanks et al., 1988) that certain conserved residues within subdomains VIB and VIII determine substrate specificity (Ser/Thr vs Tyr). In subdomain VIB, 1G5 contains the sequence NLKLEN, which closely resembles the conserved sequence DLKPEN and, in subdomain VIII, GTPEYLAPE, which matches the consensus sequence GT/
S-Y/F-APE; these sequence conservations strongly indicate Ser/ $\mathrm{Thr}$ specificity for $1 \mathrm{G} 5$.

Curiously, 1G5 is missing conserved residues in subdomains I, VIB, and VII, which have been either implicated or proven to be involved in ATP binding (Hanks et al., 1988). We do not detect the consensus ATP-binding sequence of subdomain I containing three glycine residues (G-G-G-) in 1G5; the second glycine is invariant in all known protein kinases (Fig. 2). The totally invariant aspartate residue in VIB, which is thought to stabilize ATP binding via magnesium salt bridges, is instead an asparagine residue in $1 \mathrm{G} 5$. The almost invariant glycine residue (found in 116 of 117 protein kinases as of the 1990 database compilation) of subdomain VII is replaced by a histidine residue in $1 \mathrm{G} 5$. Thus, although the putative $1 \mathrm{G} 5$ protein is highly related in sequence to several known protein kinases (in fact, it 


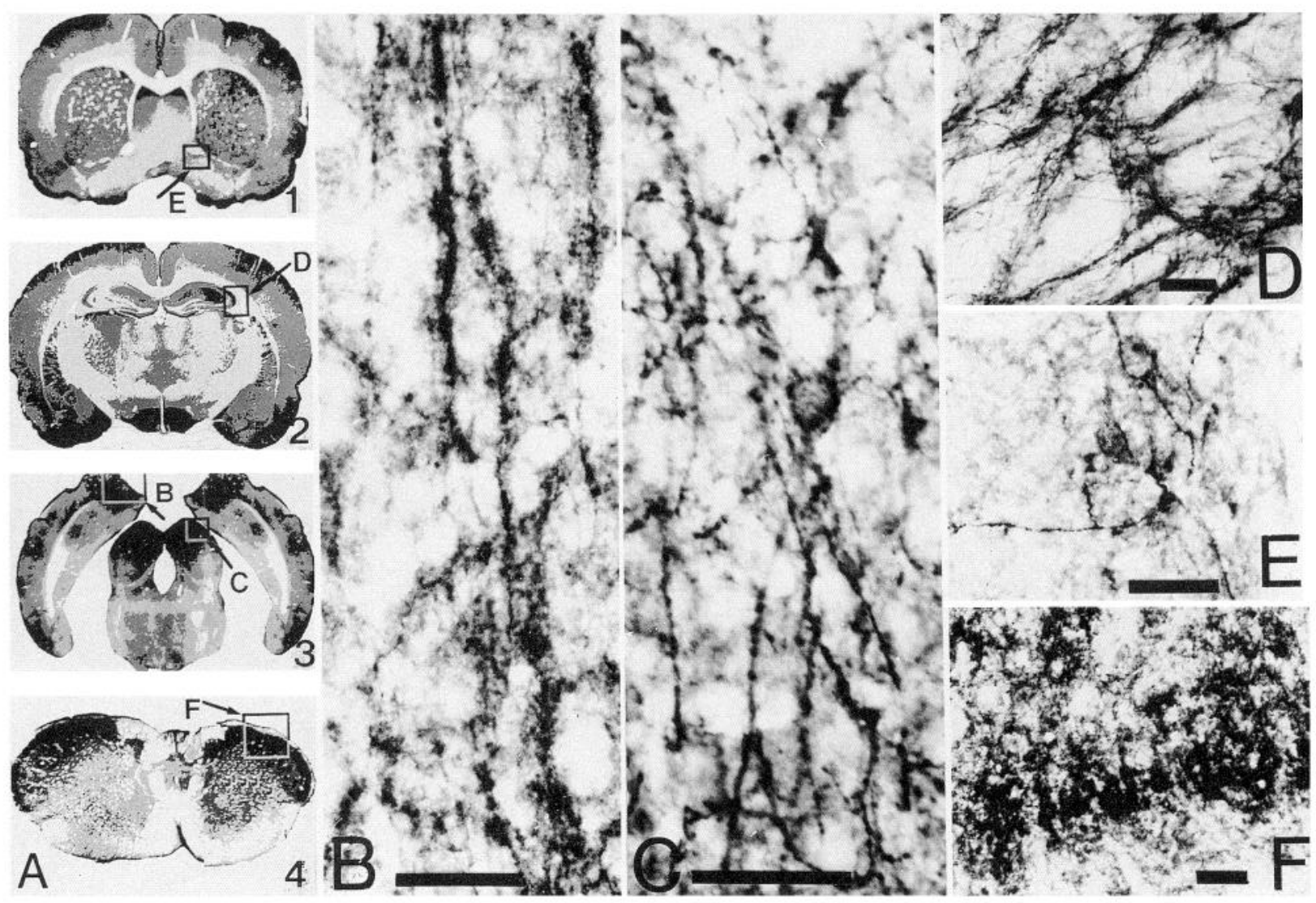

Figure 6. Survey of $1 G 5$ protein distribution by immunocytochemistry $(A, 1-4)$ with examples of neurons, dendrites, and fibers in specific locations $(B-F)$. The locations of the fields from which $B-F$ were taken are indicated by boxes in $A$. The survey scale images in $A$ are shaded from digitally scanned images in proportion to the density of the immunoreactivity, indicating the cerebral cortex, and certain subcortical areas to be the most enriched. Typical dense patterns of dendritic immunoreactivity can be seen throughout the neocortex $(B)$, in the external cortex of the inferior colliculus $(C)$, and in dense fascicles of axons with the fimbria at the lateral boundary of the hippocampal formation $(D)$ and in the spinal trigeminal tract $(F)$; both immunoreactive perikarya and fibers are seen within the bed nucleus of the stria terminalis $(E)$. Scale bars, $25 \mu \mathrm{m}$.

is as related to CaMKII and phosphorylase kinase as these are to each other), preserves the critical residues of several characteristic kinase subdomains, and undoubtedly has evolved from a kinase progenitor, it appears to be deficient in some of the signature residues that functionally define members of this protein family. Furthermore, 1G5 failed to function as a kinase with a sample substrate when expressed recombinantly, although comparably prepared CaMKII exhibited kinase function.

We considered the possibility that our $1 \mathrm{G} 5$ clones contained artifactual sequences substituting for a putative bona fide ATPbinding domain. We rejected this possibility because of three observations. First, independent cDNA clones possessed the same sequences. Second, anchored PCR performed with a primer complementary to putative subdomain VIA yielded a product that contained the same amino terminal sequence as the $5^{\prime}$ end of our cDNA clones, showing that subdomain I is truly missing from 1G5 mRNAs. Third, domains VI and VII, within the body of the 1G5 sequence and also implicated in ATP binding in protein kinases, also lack some otherwise invariant or highly conserved residues. Thus, the failure of $1 \mathrm{G} 5$ to mimic precisely stereotypical kinase catalytic domains and its failure to act enzymatically as a kinase cannot be due to a cloning artifact.

Nevertheless, the sequence similarity to protein kinases is unmistakable and extends for nearly 300 amino acids. Assuming that $1 \mathrm{G} 5$ is not vestigial, we can suggest three alternatives to explain our results. First, 1G5 may indeed be a protein kinase but we have failed to detect its activity, either because we have not offered the correct substrate or conditions, or because the recombinant protein is inactive. If so, then $1 \mathrm{G} 5$ must have a nonclassical ATP-binding site. Second, the 1 G5 protein may catalyze a calmodulin-regulated reaction other than phosphorylation, such as sulfation (although the 1G5 sequence is unrelated to those of sulfate transferases). Third, the $1 \mathrm{G} 5$ protein may act via its obvious structural similarity to protein kinases with Ser/Thr specificity to mimic some aspect of kinase activity, perhaps as a calmodulin-affected regulator of biochemical processes.

There is precedent for the latter hypothesis in the membraneassociated guanylate cyclases. These are three-domain proteins whose structural organizations (extracellular ligand-binding domain and intracellular protein Tyr kinase-like and guanylate cyclase domains) are similar to protein Tyr kinase/growth factor receptors, such as the platelet-derived growth factor receptor (Singh et al., 1988). Their Tyr kinase-like domains are missing conserved residues in subdomains I, VIB, and IX (including two of the conserved residues missing from 1G5) and no kinase activity has been measured for the proteins. Mutant forms of one of these guanylate cyclases, the atrial natriuretic peptide (ANP) receptor, from which the kinase-like domain has been 

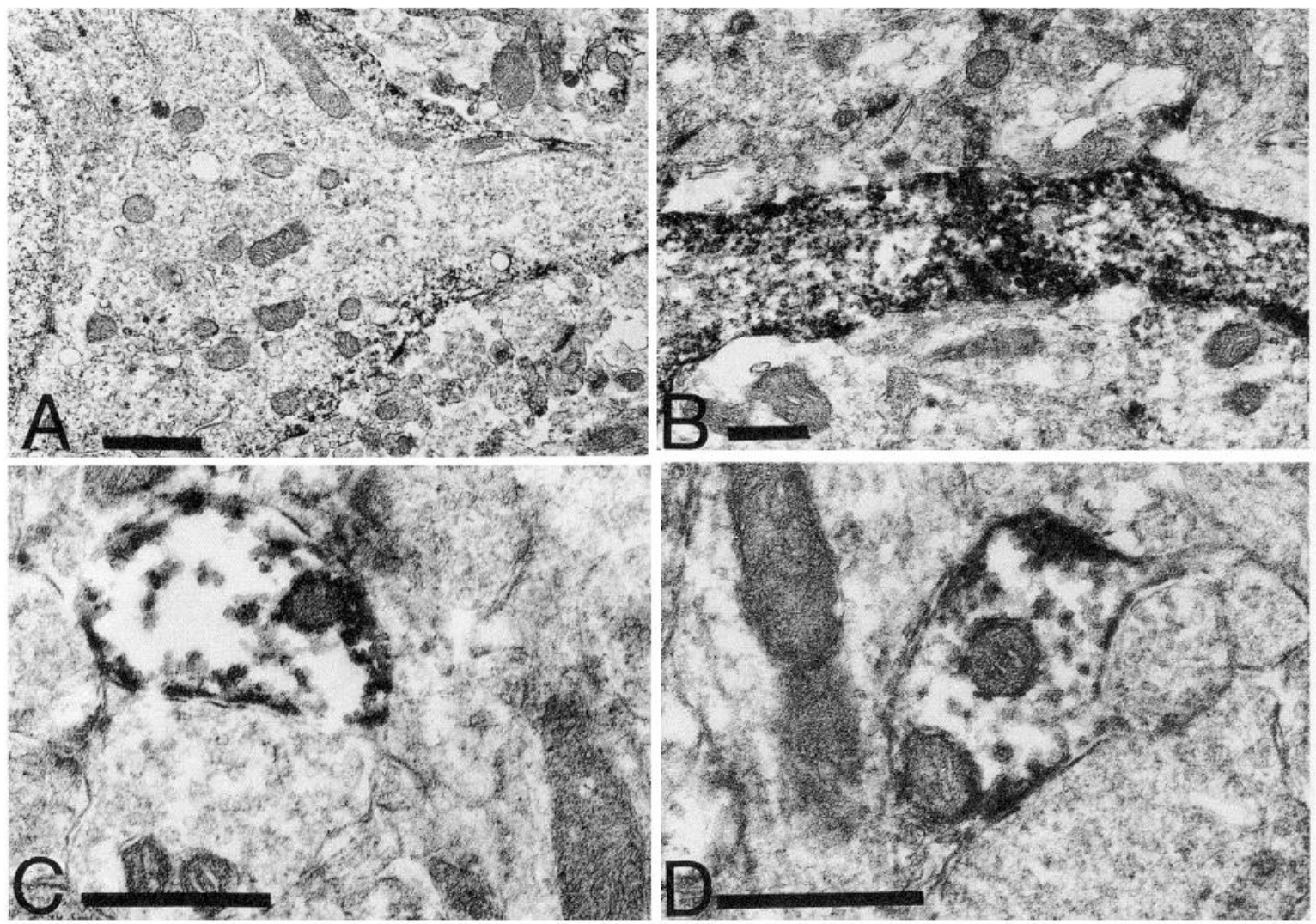

Figure 7. Ultrastructural immunoperoxidase localization of $1 \mathrm{G} 5$ in rat brain. A medium-sized pyramidal-shaped neuron of the entorhinal cortex exhibits a thin band of immunoreactivity at the cell perimeter and extending into the apical dendrite $(A)$. Immunoreactivity is also seen throughout medium-sized long dendrites of the cingulate cortex $(B)$ and within dendritic spines receiving synapses from nonimmunoreactive terminals $(C)$, as well as in synaptic terminals abutting nonimmunoreactive dendrites $(D)$. The latter findings are typical of all cortical regions examined. Scale bars: $A, 1 \mu \mathrm{m} ; B-D, 0.5 \mu \mathrm{m}$.

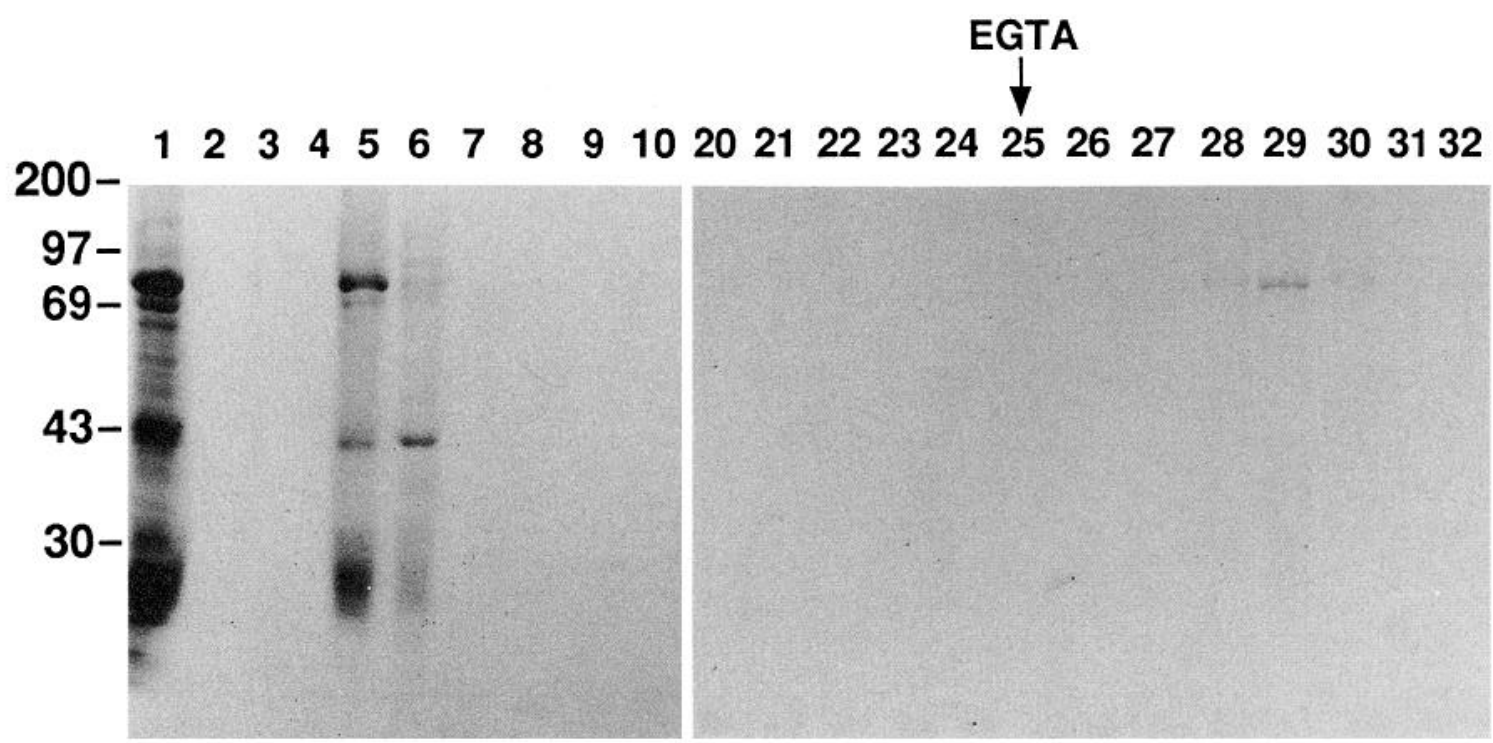

Figure 8. Binding of bacterially expressed $1 \mathrm{G} 5$ to calmodulin. Extract of IPTG-induced bacteria containing pRK-1G5 (lane 1) was applied to 17 $\mathrm{ml}$ calmodulin-sepharose column in the presence of calcium and $6 \mathrm{ml}$ fractions were collected (lanes 2-10, 20-32). The column was washed with a buffer containing $5 \mathrm{~mm}$ calcium (lanes 2-10, 20-23). A buffer containing EGTA but no calcium was applied (lanes 24-32). Equal volumes of each sample were separated by SDS gel electrophoresis and the gel stained with Coomassie blue and photographed. Lanes 11-19 were blank and are not shown. 
deleted, exhibit constitutive guanylate cyclase activity no longer requiring ANP for activation nor ATP for potentiation, suggesting that the kinase-like domain interacts with ATP, although it does not transfer phosphate, and that the domain acts in the absence of ligand as a repressor for the guanylate cyclase function (Chinkers and Garbers, 1989). By analogy, the 1G5 kinase-like domain may confer calmodulin (and hence calcium) regulation and, possibly, ATP potentiation to a biochemical function that resides either within the carboxy-terminal portion of $1 \mathrm{G} 5$ or within a protein that interacts heteromerically with $1 \mathrm{G} 5$. If the kinase-like domain of $1 \mathrm{G} 5$ plays such a role as a calcium sensor, the Ser/Thr specificity of its sequence could be vestigial.

Also of interest is the tandemly repeated sequence near the carboxy terminus of $1 \mathrm{G} 5$. A partial sequence of the monkey homolog $6 \mathrm{E} 9$ indicates complete amino acid conservation across this domain. 'Two of the seven repeated sequences contain the consensus CaMKII phosphorylation target RXXS/T (Pearson ct al., 1985), suggesting that 1G5 could itsclf be a substratc for protein kinases or that the 1 G5 kinase-like domain, through its apparent Ser/Thr specificity, might interact with the repeated sequence, depending upon $\mathrm{Ca}^{2+} /$ calmodulin availability. We considered the possibility that the repeated region might form an independent structural motif and fold into a higher-order structure, bending at the prolines that appear at eight-residue intervals. However, pilot two-dimensional nuclear magnetic resonance experiments with a 58 residue synthetic peptide containing the tandem repeats did not suggest the presence of any stable solution conformation (J. Dyson, P. Wright, and J. G. Sutcliffe, unpublished observations).

The 1G5 protein is found associated with membranes and vesicular structures in both axons and dendrites of a subset of neurons enriched in, but not restricted to, forebrain. Vesicles are not well-known structures of dendrites; however, we have previously documented the presence of vesicle-like structures in dendrites of neurons that contain secretogranin III (Ottiger et al., 1990). Here, the observation that 165 -associated vesicles are present in both axons and dendrites suggests, assuming that the vesicles at each pole are equivalent, that their function is not specialized to a particular part of the neuron. Similarly, neurons that contain $1 \mathrm{G} 5$ are at highest density in certain regions of the cerebral cortex, but are present in many other regions of the brain, thus, again assuming equivalence, their function is not anatomically restricted.

In general, there is good correspondence between the localization of sites expressing the $1 \mathrm{G} 5 \mathrm{mRNA}$ as detected by Northern blotting and in situ hybridizations, and the neurons and fibers containing the $1 \mathrm{G} 5$ protein, as detected by immunoblotting or immunocytochemistry. Minor differences between the chemical estimates made on extractions of mRNA or proteins, or the cellular estimates based on the microscopic methods can logically be attributed to the density of the detected cellular systems, the accuracy of the boundaries of the dissected brain regions, and the relative proportions of a given regional sample occupied by the detected cell systems. Thus, the correspondence was highest, most generally, for those cortical regions expressing a high level of mRNA and protein, such as the cortex and amygdaloid complex, while lesser correspondence was seen for regions such as the hypothalamus, hippocampal formation, caudate nucleus, and thalamus, in which select groups of neurons were found to express 1G5 markers within larger anatomic regions. Within the regions examined by the microscopic cellular methods, there was excellent correspondence between the in situ hybridization data and the immunocytochemistry, with the sole exception of the arcuate nucleus and the immediately adjacent premammillary nucleus. In the latter two regions, there was significant in situ hybridization, and a conspicuous lack of immunoreactivity (see Table 1). Whether this represents an artifactual outcome of either microscopic method or perhaps suggests alternative processing of the $1 \mathrm{G} 5$ protein to forms unrecognizable by our antisera remains to be determined.

Taken as a whole, those regions of the brain in which the $1 \mathrm{G} 5$ expression is most abundant share at least two potentially noteworthy features: (1) there is abundant expression within the somatosensory and auditory systems, in terms of both the primary and secondary relay nuclei for these systems, as well as their cortical terminations; (2) there is significant but somewhat less intense expression within brain systems traditionally linked to emotional (amygdaloid formation, hippocampal formation, entorhinal cortex, and striatum) and integrative (locus coeruleus, substantia nigra) operations.

Our studies suggest that the 1G5 protein is most likely a vesicle-associated membrane protein whose activity is regulated by calcium, calmodulin and, possibly, ATP and phosphorylation.

\section{References}

Aviv H, Leder P (1972) Purification of biologically active globin messenger RNA by chromatography on oligothymidylic acid-cellulose. Proc Natl Acad Sci USA 69:1408-1412.

Bagchi IC, Huang Q, Means AR (1992) Identification of amino acids essential for calmodulin binding and activation of smooth muscle myosin light chain kinase. J Biol Chem 267:3024-3029.

Bennett MK, Kennedy MB (1987) Deduced primary structure of the $\beta$ subunit of brain type II $\mathrm{Ca}^{2+} /$ calmodulin-dependent protein kinase detcrmined by molecular cloning. Proc Natl Acad Sci USA 84:1794 1798.

Bernal J, Godbout M, Hasel KW, Travis GH, Sutcliffe JG (1990) Patterns of cerebral cortex mRNA expression. J Neurosci Res 27: 153-158.

Bloom FE, Battenberg ELF, Milner RJ, Sutcliffe JG (1985) Immunocytochemical mapping of 1B236: a brain specific neuronal protein deduced from the sequence of its mRNA. J Neurosci 5:1781-1802.

Bourouis M, Moore P, Ruel L, Grau Y, Heitzler P, Simpson P (1990) An early embryonic product of the gene shaggy encodes a serine/ threonine protein kinase related to the $\mathrm{CDC} 28 / \mathrm{cdc} 2+$ subfamily. EMBO J 9:2877-2884.

Brutlag DL, Dautricourt JP, Maulik S, Relph J (1990) Improved sensitivity of biological sequence database searches. Comp Appl Biosci 6:237-245.

Buck L, Axel R (1991) A novel multigene family may encode odorant receptors: a molecular basis for odor recognition. Cell 65:175-187.

Bulleit RF, Bennett MK, Molloy SS, Hurley JB, Kennedy MB (1988) Conserved and variable regions in the subunits of brain type II $\mathrm{Ca}^{2+}$ / calmodulin-dependent protein kinase. Neuron 1:63-72.

Chinkers M, Garbers DL (1989) The protein kinase domain of the ANP receptor is required for signaling. Science 245:1392-1394.

Danielson PE, Forss-Petter S, Brow MA, Calavetta L, Douglass J, Milner R, Sutcliffe JG (1988) p1B15: a cDNA clone of the rat mRNA encoding cyclophilin. DNA 7:261-267.

Forss-Petter S, Danielson P, Battenberg E, Bloom F, Sutcliffe JG (1989) Nucleotide sequence and cellular distribution of rat chromogranin $B$ (secretogranin I) mRNA in the neuroendocrine system. J Mol Neurosci $1: 63-75$.

Frohman MA, Dush MK, Martin GR (1988) Rapid production of full-length cDNAs from rare transcripts: amplification using a single gene-specific oligonucleotide primer. Proc Natl Acad Sci USA 85: 8998-9002.

Green N, Alexander H, Olson A, Alexander S, Shinnick TM, Sutcliffe JG, Lerner RA (1982) Immunogenic structure of the influenza virus hemagglutinin. Cell 28:477-487.

Gubler U, Hoffman BJ (1983) A simple and very efficient method for generating cDNA libraries. Gene 25:263-269. 
Hanks SK, Quinn AM (1991) Protein kinase catalytic domain sequence database: identification of conserved features of primary structure and classification of family members. Methods Enzymol 200: $38-62$.

Hanks SK, Quinn AM, Hunter T (1988) The protein kinase family: conserved features and deduced phylogeny of the catalytic domains. Science 241:42-52.

Hashimoto Y, Soderling TR (1987) Calcium calmodulin-dependent protein kinase II and calcium phospholipid-dependent protein kinase activities in rat tissues assayed with a synthetic peptide. Arch Biochem Biophys 252:418-425.

Higgins GA, Wilson MC (1987) In situ hybridization for mapping the neuroanatomical distribution of novel brain mRNAs. In: In situ hybridization applications to neurobiology (Valentino KL, Eberwine $\mathrm{JH}$, Barchas JD, eds), pp 146-162. London: Oxford UP.

Hunter T (1991) Protein kinase classification. Methods Enzymol 200: 3-37.

Kennedy MB, Bennett MK, Erondu NE (1983) Biochemical and immunochemical evidence that the "major postsynaptic density protein" is a subunit of a calmodulin-dependent protein kinase. Proc Natl Acad Sci USA 80:7357-7361.

Maniatis T, Fritsch EF, Sambrook J (1982) Molecular cloning: a laboratory manual. Cold Spring Harbor, NY: Cold Spring Harbor Laboratory.

Maxam AM, Gilbert W (1977) A new method of sequencing DNA. Proc Natl Acad Sci USA 74:560-564.

McLeod M, Stein M, Beach D (1987) The product of the $m e i 3^{+}$gene, expressed under the mating-type locus, induces meiosis and sporulation in fission yeast. EMBO J 6:729-736.

Miller SG, Patton BL, Kennedy MB (1988) Sequences of autophosphorylation sites in neuronal type II CaM kinase that control $\mathrm{Ca}^{2+}$ independent activity. Neuron 1:593-604

Ohsake S, Watanabe A, Sekihara S, Ikai A, Yamauchi T (1990) Expression of a catalytically active polypeptide of calmodulin-dependent protein kinase II $\alpha$ subunit in Escherichia coli. Biochem Biophys Res Commun 170:705-712.

Ottiger H-P, Battenberg EF, Tsou A-P, Bloom FE, Sutcliffe JG (1990) 1B1075: a brain- and pituitary-specific mRNA that encodes a novel chromogranin/secretogranin-like component of intracellular vesicles. J Neurosci 10:3135-3147.

Pearson RB, Woodgett JR, Cohen P, Kemp BE (1985) Substrate specificity of multifunctional calmodulin-dependent protein kinase. J Biol Chem 260:14471-14476.

Proudfoot NJ, Brownlee GG (1976) $3^{\prime}$ noncoding region sequences in eukaryotic messenger RNA. Nature 263:211-214.

Rogers S, Wells R, Rechsteiner M (1986) Amino acid sequences common to rapidly degraded proteins: the PEST hypothesis. Science 234: 364-368.
Sambrook J, Fritsch EF, Maniatis T (1989) Molecular cloning: a laboratory manual. Cold Spring Harbor, NY: Cold Spring Harbor Laboratory.

Sanger F, Nicklen S, Coulson AR (1977) DNA sequencing with chain terminating inhibitors. Proc Natl Acad Sci USA 74:5463-5467.

Silva AJ, Stevens CF, Tonegawa S, Wang Y (1992a) Deficient hippocampal long-term potentiation in $\alpha$-calcium-calmodulin kinase II mutant mice. Science 257:201-206.

Silva AJ, Paylor R, Wehner JM, Tonegawa S (1992b) Impaired spatial learning in $\alpha$-calcium-calmodulin kinase II mutant mice. Science 257 : 206-211.

Singh S, Lowe DG, Thorpe DS, Rodriguez H, Kuang W-J, Dangott LJ, Chinkers M, Goeddel DV, Garbers DL (1988) Membrane guanylate cyclase is a cell-surface receptor with homology to protein kinases. Nature 334:708-712.

Skcnc JHP (1989) Axonal growth-associated proteins. Annu Rev Neurosci $12: 127-156$.

Studier FW, Rosenberg AH, Dunn JJ, Dubendorff JW (1990) Use of T7 RNA polymerase to direct expression of cloned genes. Methods Enzymol 185:60-88.

Sutcliffe JG (1988) mRNA in the mammalian central nervous system. Annu Rev Neurosci 11:157-198.

Sutcliffe JG, Milner RJ, Bloom FE, Lerner RA (1982) Common 82 nucleotide sequence unique to brain RNA. Proc Natl Acad Sci USA 79:4942-4946.

Sutcliffe JG, Milner RJ, Shinnick TM, Bloom FE (1983) Identifying the protein products of brain-specific genes with antibodies to chemically synthesized peptides. Cell 33:671-682.

Thomas PS (1980) Hybridization of denatured RNA and small DNA fragments transferred to nitrocellulose. Proc Natl Acad Sci USA 77: 5201-5215.

Towbin H, Staehelin T, Gordon J (1979) Electrophoretic transfer of proteins from polyacrylamide gels to nitrocellulose sheets: procedure and some applications. Proc Natl Acad Sci USA 76:4350-4354.

Travis GH, Sutcliffe JG (1988) Phenol emulsion-enhanced DNA-driven subtractive cDNA cloning: isolation of low abundance monkey cortex-specific mRNAs. Proc Natl Acad Sci USA 85:1696-1700.

Travis GH, Naus CG, Morrison JH, Bloom FE, Sutcliffe JG (1987) Subtractive cloning of complementary DNAs and analysis of messenger RNAs with regional heterogeneous distributions in primate cortex. Neuropharmacology 26:845-854.

Watson JB, Battenberg EF, Wong KK, Bloom FE, Sutcliffe JG (1990) Subtractive cDNA cloning of $\mathrm{RC} 3$, a rodent cortex-enriched mRNA cncoding a novel 78 residue protein. J Neurosci Res 26:397-408.

Zhou Q-Y, Grandy DK, Thambi L, Kushner JA, Van Tol HHM, Cone R, Pribnow D, Salon J, Bunzow JR, Civelli O (1990) Cloning and expression of human and rat $D_{1}$ dopamine receptors. Nature 347:7679. 